\title{
Makalah \\ Pendidikan Kesehatan Tentang Penyakit Menular
}

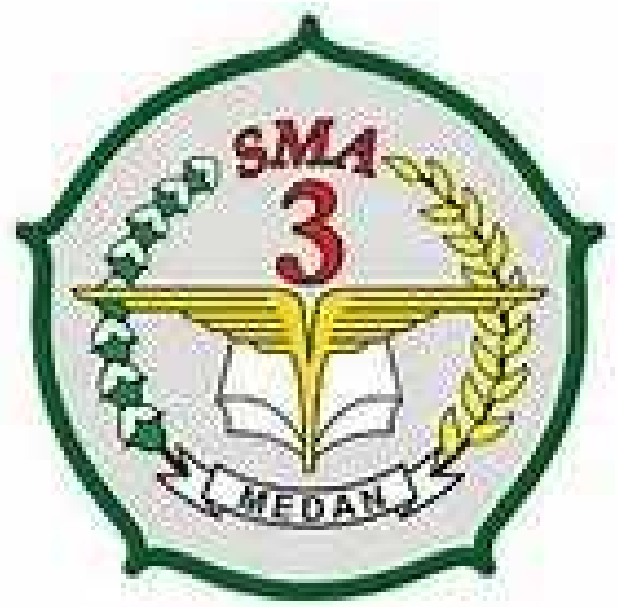

OLEH

\author{
Raihan Abrar \\ X MIA 3 \\ SMA NEGERI 3 \\ MEDAN T.A. \\ 2019/2020
}





\section{Kata pengantar}

Puji syukur penulis ucapakan kepada Allah SWT, yang telah memberikan rahmat dan karunia-Nya sehingga makalah yang berjudul "Pendidikan Kesehatan Tentang Penyakit Menular" ini dapat diselesaikan dengan baik. Tidak lupa shalawat dan salam semoga terlimpahkan kepada Rasulullah Muhammad SAW, keluarganya, sahabatnya, dan kepada kita selaku umatnya.

Makalah ini penulis buat untuk melengkapi tugas pelajaran PJOK. Saya ucapkan terima kasih kepada semua pihak yang telah membantu dalam penyusunan makalah ini. Dan saya juga menyadari akan pentingnya sumber bacaan dan referensi internet yang telah membantu dalam memberikan informasi yang akan menjadi bahan makalah.

Saya juga mengucapkan terima kasih kepada bapak guru Suyono S.Pd, M.Or sebagai guru bidang studi yang telah banyak memberi petunjuk dan semua pihak yang telah memberikan arahan serta bimbingannya selama ini sehingga penyususan makalah dapat dibuat dengan sebaikbaiknya. Saya menyadari masih banyak kekurangan dalam penulisan makalah ini sehingga saya mengharapkan kritik dan saran yang bersifat membangun demi penyempurnaan makalah ini.

Saya mohon maaf jika di dalam makalah ini terdapat banyak kesalahan dan kekurangan, karena kesempurnaan hanya milik Yang Maha Kuasa yaitu Allah SWT, dan kekurangan pasti milik kita sebagai manusia. Semoga makalah ini dapat bermanfaat bagi kita semua.

Medan, 7 Mei 2020

Raihan Abrar 


\section{Daftar Isi}

Judul

Kata Pengantar Daftar

Isi

Abstrak...

....1

BAB

I Pendahuluan . .2

1.1. Latar

Belakang 2

1.2. Identifikasi

Masalah 5

1.3. Batasan

Masalah............... 5

1.4. Rumusan

Masalah ............. 5

1.5. Tujuan

Masalah ............... 6

BAB

II Pembahasan 7

2.1. Kajian

Teori................. 7

2.1.1. Hakikat

Penyakit Menular 7

2.1.2. Jenis-Jenis Penyakit Menular dan Penyebabnya......7

2.1.3. Penyebaran Penyakit Menular Secara Umum. 10

2.1.4. Dampak Buruk dari Penyakit Menular ... 10

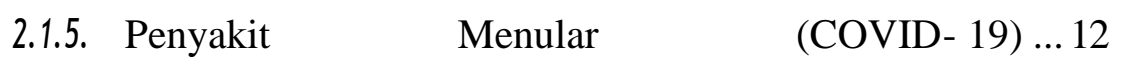

2.1.5.1. Pengertian

COVID- 19 ...... 12 
2.1.5.2. Faktor Resiko Infeksi Corona Virus ... 13

2.1.5.3. Tanda dan Gejala ........... 13

2.1.5.4. Penularan ...............................................................................................................

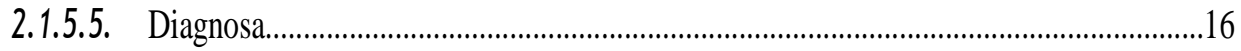

2.1.5.6. Komplikasi.................................................................................................17

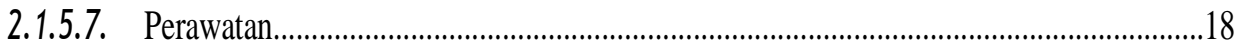

2.1.5.8. Pemberian Obat- obatan........... 18 


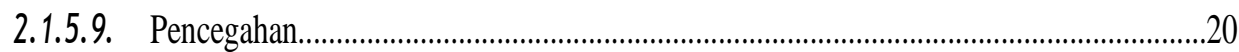

BAB

III Penutup .............. 23

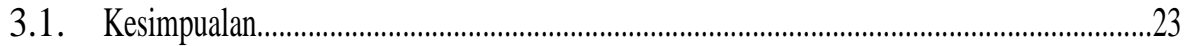

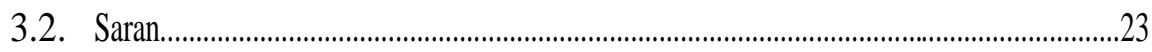

Daftar

Pustaka.................24 


\begin{abstract}
Abstrak
Tujuan : penyakit menular merupakan penyakit yang harus diwaspadai karena menjadi salah satu penyebab utama kematian di dunia. Beberapa dari penyakit menular dapat ditularkan melalui udara, dan pada umumnya, penyakit menular dapat menyebabkan kematian. Kondisi ini semakin buruk dengan kondisi lingkungan yang tidak sehat menyebabkan beberapa penyakit infeksi akut yang berbahaya menyerang manusia seperti penyakit yang bersumber pada binatang. maka, kita harus menjaga kesehatan tubuh dengan mengonsumsi vitamin $\mathrm{C}$ guna membangun daya tahan tubuh, menjaga kebersihan diri dan linkungan, memakan makanan yang sehat dan bergzi, dan olahraga yang teratur. Dengan itu, kita dapat menghindari tertularnya penyakit menular atau memperlambat penyebarannya.
\end{abstract}

Penyakit ini dapat berpindah dari satu orang ke orang lain, penularannya tersebut bisa terjadi secara langsung atau tidak langsung dan juga bisa menular melalui perantara atau penghubung. Penyakit menular biasanya ditandai dengan adanya penyebab penyakit yang hidup dan bisa berpindah menyerang inang (penderita). Penyakit menular disebabkan oleh agen biologi seperti halnya virus, bakteria, atau parasit dan bukan disebabkan oleh faktor fisik seperti luka bakar atau zat kimia (keracunan).

Kata kunci : penyakit, virus, vitamin C 


\section{BAB I}

\section{Pendahuluan}

\subsection{Latar Belakang}

Penyakit menular menjadi salah satu penyebab utama kematian di Dunia.

Penyebabnya munculnya penyakit baru (new emerging disease) dan munculnya kembali penyakit menular yang lama (re-emerging disease) membuat Indonesia menanggung beban berlebih dalam penanggulangan penyakit (triple burden disease) (Kemenkes, 2013). Kondisi ini semakin buruk dengan kondisi lingkungan yang tidak sehat menyebabkan beberapa penyakit infeksi akut yang berbahaya menyerang manusia seperti penyakit yang bersumber pada binatang seperti leptospirosis (Widarso dan Wilfried, 2008).

Penyakit menular menjadi masalah dalam kesehatan masyarakat di Indonesia dan hal ini sering timbul sebagai Kejadian Luar Biasa (KLB) yang menyebabkan kematian penderitanya. Salah satu fokus perhatian pemerintah di bidang kesehatan masyarakat adalah upaya untuk memutus rantai penyebaran Human Immunodeficiency Virus (HIV) dan AIDS (Hutapea, Sarumpaet, \& Rasmaliah, 2013). Acquired Immunodeficiency Syndrome (AIDS) merupakan suatu sindrom yang disebabkan oleh Human Immunodeficieny Virus (HIV). Virus tersebut melumpuhkan selsel darah putih yang berfungsi dalam kekebalan tubuh (McCance, 2010). Asia merupakan wilayah dengan penduduk terinfeksi HIV terbanyak kedua di dunia setelah Sub Sahara Afrika.

Berdasarkan data UNAIDS tahun 2014, di Asia terdapat 5 juta orang terinfeksi HIV. Jumlah kasus baru 340.000 orang terinfeksi HIV (UNAIDS, 2014). Kasus HIV/AIDS di Indonesia harus ditanggapi dengan serius karena jumlah penderita terus meningkat dari tahun ke tahun. Di Indonesia, dari 1 Januari sampai 30 September 2013 tercatat orang yang terinfeksi HIV sejumlah 20.413 dan penderita AIDS sejumlah 2.763, jumlah kematiannya adalah 318. Sementara itu, jumlah penderita dari 1 Januari sampai 30 September 2014 tercatat kasus HIV sejumlah 22.689 dan AIDS 1.876, jumlah kematiannya adalah 211. Provinsi dengan kasus HIV dan AIDS terbanyak yang 
dilaporkan adalah Papua, diikuti Jawa Timur, DKI Jakarta, Bali, Jawa Barat (Depkes RI, 2014). Cara penularan penyakit HIV/AIDS ini seperti heteroseksual, penggunaan narkoba suntik, homoseksual, perinatal, dan pekerja seks. Kasus yang terbanyak disebabkan karena heteroseksual yaitu hubungan seksual tanpa pengaman (Hutapea, 2011). Penyakit AIDS ini juga bisa menyebabkan infeksi oportunistik, seperti TBC, diare kronis, candidiasis oro-faringeal, dermatitis generalisata, dan limfadenopati generalisata persisten. Salah satu infeksi oportunistik yang bersifat fatal seperti toxoplasmosis, pneumonia (Duarsa, 2014). Salah satu faktor risiko terjadinya penularan AIDS adalah tingkat pendidikan yang rendah sehingga pengetahuan tentang penularan dan bahaya HIV/AIDS kurang. Padahal HIV/AIDS ini dapat dicegah dengan cara yang sederhana misalnya dengan memakai kondom, tidak berganti - ganti pasangan, dengan penatalaksanaan yang baik dapat meningkatkan kualitas hidup penderita HIV/AIDS (Duarsa, 2014). Faktor yang mempengaruhi prognosis penderita HIV/AIDS adalah jumlah CD4 HIV menargetkan sel CD4 dengan cara mengikat permukaan sel CD4, memasuki sel CD4 dan menjadi bagiannya, kemudian virus melanjutkan untuk bereplikasi, yang mengarah ke penurunan bertahap dari sel CD4 dan menjadi AIDS (WebMD, 2016). AIDS adalah tahap infeksi HIV yang terjadi ketika sistem kekebalan tubuh rusak parah dan menjadi rentan terhadap infeksi oportunistik. Ketika jumlah sel CD4 turun di bawah $200 \mathrm{sel} / \mathrm{mm} 3$, maka dianggap telah berkembang menjadi AIDS. Dalam seseorang dengan sistem kekebalan tubuh yang sehat, jumlah CD4 antara 500 dan 1.600 sel/mm3. Penderita HIV juga dianggap telah berkembang menjadi AIDS jika terdapat satu atau lebih oportunistik penyakit, terlepas dari jumlah CD4 (AIDS.gov, 2016). Selain itu, jumlah virus HIV dalam darah, umur, infeksi hepatitis B atau hepatitis C, penggunaan jarum suntik, dan keseriusan dalam pengobatan HIV juga berpengaruh pada prognosis penyakit HIV/AIDS (Carter \& Hughson, 2012).

Saat ini, kita dikejutkan dengan kemunculan virus jenis baru yang belum pernah diidentifikasi sebelumnya pada manusia yaitu Coronavirus Disease (COVID-19). Coronavirus (CoV) adalah keluarga besar virus yang menyebabkan penyakit mulai dari gejala ringan sampai berat. Ada setidaknya dua jenis coronavirus yang diketahui menyebabkan penyakit yang dapat menimbulkan gejala berat seperti Middle East Respiratory Syndrome (MERS) dan Severe Acute Respiratory Syndrome (SARS). 
Coronavirus Disease (COVID-19) adalah virus jenis baru yang belum pernah diidentifikasi sebelumnya pada manusia. Virus corona adalah zoonosis (ditularkan antara hewan dan manusia). Penelitian menyebutkan bahwa SARS ditransmisikan dari kucing luwak (civet cats) ke manusia dan MERS dari unta ke manusia. Beberapa coronavirus yang dikenal beredar pada hewan namun belum terbukti menginfeksi manusia. Manifestasi klinis biasanya muncul dalam 2 hari hingga 14 hari setelah paparan. Tanda dan gejala umum infeksi coronavirus antara lain gejala gangguan pernapasan akut seperti demam, batuk dan sesak napas. Pada kasus yang berat dapat menyebabkan pneumonia, sindrom pernapasan akut, gagal ginjal, dan bahkan kematian. Pada 31 Desember 2019, WHO China Country Office melaporkan kasus pneumonia yang tidak diketahui etiologinya di Kota Wuhan, Provinsi Hubei, Cina. Pada tanggal 7 Januari 2020, Cina mengidentifikasi pneumonia yang tidak diketahui etiologinya tersebut sebagai jenis baru coronavirus (coronavirus disease, COVID-19). Pada tanggal 30 Januari 2020 WHO telah menetapkan sebagai Public Health Emergency of International Concern (PHEIC). Penambahan jumlah kasus COVID-19 berlangsung cukup cepat dan sudah terjadi penyebaran ke luar wilayah Wuhan dan negara lain.

Sampai dengan 16 Februari 2020, secara global dilaporkan 51.857 kasus konfimasi di 25 negara dengan 1.669 kematian (CFR 3,2\%). Rincian negara dan jumlah kasus sebagai berikut: China 51.174 kasus konfirmasi dengan 1.666 kematian, Jepang (53 kasus, 1 Kematian dan 355 kasus di cruise ship Pelabuhan Jepang), Thailand (34 kasus), Korea Selatan (29 kasus), Vietnam (16 kasus), Singapura (72 kasus), Amerika Serikat (15 kasus), Kamboja (1 kasus), Nepal (1 kasus), Perancis (12 kasus), Australia (15 kasus), Malaysia (22 kasus), Filipina (3 kasus, 1 kematian), Sri Lanka (1 kasus), Kanada (7 kasus), Jerman (16 kasus), Perancis (12 kasus), Italia (3 kasus), Rusia (2 kasus), United Kingdom (9 kasus), Belgia (1 kasus), Finlandia (1 kasus), Spanyol (2 kasus), Swedia (1 kasus), UEA (8 kasus), dan Mesir (1 Kasus). Diantara kasus tersebut, sudah ada beberapa petugas kesehatan yang dilaporkan terinfeksi. Tanda-tanda dan gejala klinis yang dilaporkan sebagian besar adalah demam, dengan beberapa kasus mengalami kesulitan bernapas, dan hasil rontgen menunjukkan infiltrat pneumonia luas di kedua paru. Menurut hasil penyelidikan epidemiologi awal, sebagian besar kasus di Wuhan memiliki riwayat bekerja, menangani, atau pengunjung yang sering berkunjung 
ke Pasar Grosir Makanan Laut Huanan. Sampai saat ini, penyebab penularan masih belum diketahui secara pasti. WHO melaporkan bahwa penularan dari manusia ke manusia terbatas (pada kontak erat dan petugas kesehatan) telah dikonfirmasi di China maupun negara lain.

Berdasarkan kejadian MERS dan SARS sebelumnya, penularan manusia ke manusia terjadi melalui droplet, kontak dan benda yang terkontaminasi, maka penularan COVID-19 diperkirakan sama. Rekomendasi standar untuk mencegah penyebaran infeksi adalah melalui cuci tangan secara teratur, menerapkan etika batuk dan bersin, menghindari kontak secara langsung dengan ternak dan hewan liar serta menghindari kontak dekat dengan siapa pun yang menunjukkan gejala penyakit pernapasan seperti batuk dan bersin. Selain itu, menerapkan Pencegahan dan Pengendalian Infeksi (PPI) saat berada di fasilitas kesehatan terutama unit gawat darurat.

\subsection{Identifikasi masalah}

Dari latar belakang yang sudah disebutkan di atas, serta belum adanya data penelitian, Maka diperlukan penelitian lebih lanjut untuk penyakit menular.

\subsection{Batasan Masalah}

Batasan masalah yang didasarkan pada latar belakang adalah sebagai berikut :

2. Penyakit yang dibahas adalah COVID-19 yang merupakan virus jenis baru yang belum pernah diidentifikasi sebelumnya pada manusia.

3. Penyakit ini dapat menyerang semua umu, semua jenis kelamin, dan ras yang ada di dunia.

4. Banyak gejala yang tertuju ke penyakit COVID-19, secara umum gejala klinisnya adalah demam, batuk, flu, sesak napas, sakit tenggorokan.

\subsection{Rumusan masalah}


Dalam makalah yang berjudul aktivitas Kebugarann Jasmani yang Berhubungan dengan Kesehatan mengangkat masalah-masalah sebagai berikut:

1. Apa pengertian dari penyakit menular?

2. Apa saja jenis-jenis penyakit menular dan penyebabnya?

3. Bagaimana cara penyebaran penyakit menular secara umum?

4. Apa saja dampak buruk dari penyakit menular?

5. Apa itu penyakit menular(COVID-19)?

6. Apa pengertian dariCOVID-19?

7. Apa saja faktor resiko infeksi corona virus?

8. Apa saja tanda dan gejala COVID-19

9. Bagaimana penularannya?

10. Bagaimana cara menentukan diagnosanya?

11. Apa saja komplikasi yang didapat oleh penderita?

12. Bagaimana perawatannya?

13. Apa saja obat-obatan yangdiberikan?

14. Bagaimana pencegahannya?

\subsection{Tujuan Masalah}

Pembuatan makalah ini bertujuan untuk

1. Untuk mengetahui pengertian dari penyakit menular.

2. Untuk mengetahui jenis-jenis penyakit menular dan penyebabnya.

3. Untuk mengetahui penyebaran penyakit menular secara umum.

4. Untuk mengetahui dampak buruk dari penyakit menular. 
5. Untuk mengetahui penyakitmenular(COVID-19).

6. Untuk megetahui pengertian dari COVID-19.

7. Untuk mengetahui faktor resiko infeksi corona virus.

8. Untuk mengetahui tanda dan gejalanya.

9. Untuk mrngrtahui carapenularannya.

10. Untuk mengetahui cara menentukandiagnosanya.

11. Untuk mengetahui komplikasi yang di dapat oleh penderita.

12. Untuk mengetahui caraperawatannya.

13. Untuk mengetahui obat-obatan apa yang diberikan.

14. Untuk mengethui carapencegahannya.

\section{BAB II}

\section{Pembahasan}

\subsection{Kajian Teori}

\subsubsection{Hakikat Penyakit Menular}

Penyakit menular menurut para ahli adalah sebuah penyakit yang dapat 
berpindah dari satu orang ke orang lain. Penularan tersebut bisa terjadi secara langsung atau tidak langsung dan juga bisa menular melalui perantara atau penghubung. Penyakit menular biasanya ditandai dengan adanya penyebab penyakit yang hidup dan bisa berpindah menyerang inang (penderita).

Di dunia medis, pengertian penyakit menular atau biasa disebut penyakit infeksi merupakan penyakit yang disebabkan oleh agen biologi seperti halnya virus, bakteria, atau parasit dan bukan disebabkan oleh faktor fisik seperti luka bakar atau zat kimia (keracunan).

\subsubsection{Jenis-Jenis Penyakit Menular dan Penyebabnya}

Berikut ini adalah macam jenis atau contoh penyakit menular yang biasa kita temui di tengah tengah masyarakat.

\section{Diare}

Infeksi rotavirus adalah adalah infeksi virus yang menyebabkan peradangan di saluran pencernaan. Infeksi rotavirus menjadi penyebab umum diare pada bayi dan anak-anak, terutama di negara-negara dengan sanitasi lingkungan yang kurang baik.

Gejalainfeksi rotavirus bisa muncul setelah 2 hari terpapar virusini. Salah satu gejala yang paling sering terjadi adalah diare. Diare yang disebabkan oleh infeksi virus ini dapat menyebabkan hilangnya cairan dari dalam tubuh dalam waktu yang cepat, sehingga rentan terjadidehidrasi.

Diare sering kali mudah menjangkiti orang, entah karena salah makan atau karena hal lainnya. Perlu diketahui bahwa diare bisa menular kepada orang melalui virus dengan perantara atau media seperti diatas. Penyebab diare selain dari penularan juga bisa akibat dari makan makanan yang telah terkontaminasi oleh bakteri yang dibawa oleh lalat atau sejenisnya. 


\section{Malaria}

Malaria juga merupakan penyakit menular yang bisa disalurkan melalui nyamuk. Nyamuk jenis ini berbeda dengan nyamuk biasanya, sering disebut dengan nyamuk malaria. Anda bisa menggunakan lotion anti nyamuk untuk mencegah gigitan nyamuk tersebut. Salah satu tempat kesukaan nyamuk malaria adalah tempat tempat genangan air, jadi kita harus selalu menjaga kebersihan lingkungan dan memastikan tidak ada genangan air disekitarrumah.

\section{Tifus}

Penderita tifus biasanya akan mengalami kekurangan cairan dan tubuh terasa lemas. Nah, tifus ini sering dialami oleh masyarakat Indonesia. Penyebabnya adalah bakteri Salmonella Thypi yang merupakan penular tifus. Dengan menjaga kebersihan dan menjaga kehigienisan makanan atau minuman yang dikonsumsi dapat membantu menghindari penyakit menular ini.

\section{Batuk}

Salah satu penyakit yang mudah menular adalah batuk. Sebab penyebarannya dapat melalui udara. Orang yang batuk dan lupa tidak memakai masker dapat menyebar virus yang jika dihirup orang lain, bisa meyebabkan batuk ke orang tersebut. Untuk menghindari batuk, Anda bisa memakai masker atau pelindung lainya. Penyakit lain yang berhubungan dengan batuk pun bisa menyebar melalui udara, jadi untuk Anda pastikan bahwa daya tahan tubuh kuat dan mengonsumsi vitamin $\mathrm{C}$ yang cukup.

\section{Penyakit Menular Seksual}

Selain ke empat penyakit diatas, ada penyakit menular berbahaya yang menghantui masyarakat Indonesia yakni PMS (Penyakit Menular Seksual). Penyebabnya adalah virus yang lama kelamaan menyebabkan penderitanya lemah. Penderita penyakit seks menular ini bisamenjangkiti orang lain melalui kontak cairan seperti ludah atau air susu. Anda diwajibkan untuk selalu mewaspadai terhadap penyakit seks menular ini dengan 
melakukan seks sehat kepada pasangan yang sah, tidak bergonta ganti pasangan serta menghindari kontak caira dengan si penderita (darah, ludah dan ASI).

\section{Penyakit Menular Hepatitis}

Penyakit berikutnya yang bisa menular ke orang lain adalah hepatitis atau biasa disebut dengan penyakit kuning. Hepatitis adalah istilah umum penyakit yang merujuk pada peradangan yang terjadi di hati. Hepatitis umumnya disebabkan oleh infeksi virus, meskipun juga dapat disebabkan oleh kondisi lain. Beberapa penyebab hepatitis selain infeksi virus adalah kebiasaan minum alkohol, penyakit autoimun, serta zat racun atau obat-obatan tertentu. Pencegahan penyakit menular hepatitis ini bisa kita lakukan dengan cara menghindari kontak langsung dengan si penderita dan jangan mengonsumsi makanan atau minuman yang cara pemasakannya kurang baik.

Salah satu penyebaran hepatitis adalah ketika melakukan tranfusi darah. Ketika transfusi darah, Anda atau anggota keluarga harus senantiasa waspada dan menanyakan apakah semua peralatan yang digunakan sudah steril atau belum. Selain itu, kita juga harus memakan makanan yang sehat.

\section{Demam Berdarah}

Seperti yang kita tahu bahwa nyamuk Aedes Aegypti merupakan agen penular penyakit Demam Berdarah. Nyamuk jenis ini bisa diberantas dengan senantiasa menjaga kebersihan lingkungan sekitar dan mengikuti program pemerintah yaitu $3 \mathrm{M}$ dibarengi dengan keamanan personal yakni menggunakan lotion anti nyamuk, kipas angin, sprai pengusir nyamuk ataupun bisa menggunakan AC yang bisa mengusir nyamuk.

\section{8. $\mathrm{TBC}$}

TBC adalah penyakit yang menjadi momok bagi masyarakat di Indonesia. Pasalnya penyebaran TBC tergolong cepat dan mudah menjangkiti tubuh. Penularan TBC (Tuberculosis) ini melalui bakteri. Untuk mencegah penyakit menular ini pastikan daya tubuh Anda kuat dan pakailah masker dalam menjaga tubuh dari penularan penyakit 
TBC.

\subsubsection{Penyebaran Penyakit Menular Secara Umum}

Cara penyebaran penyakit menular secara umum yaitu :

1. Media Langsung dari Orang terjangkit kepada orang lain (biasanya melalui permukaan kulit)

2. Media udara juga bisa menjadi media dalam penularan penyakit secara langsung atau tidak langsung, karena udara sisa pernafasan tersebut bisa saja mengandung virus atau bakteri dan terkandung dalam air yang disebut dengan borne disease.

3. Media air pun bisa menjadi penularan penyakit secara langsung maupun tidak langsung.

\subsubsection{Dampak buruk dariPenyakit Menular}

Berikut adalah dampak buruk dari penyakit menular

1. Dampak akibat mengidap penyakitTBC

TBC merupakan penyakit yang mudah menular, hanya dengan berada disekitar penderita dengan tidak memakai alat pengaman saja kemungkinan orang tersebut bisa tertular. Hal tersebut bisa terjadi melalui air liur yang keluar ketika bersin atau batuk. Jika tidak segera ditangani TBC akan bisa cepat menular.

Akibat TBC ini, seseorang biasanya akan batuk secara terus menerus dan bisa mengeluarkan darah. Hal hal yang dapat menularkan TBC ke orang lain adalah Berjabat tangan dengan penderita, berciuman, memakai sikat gigi yang sama, atau berbagi 
makanan dan minuma dengan si penderita TBC.

Rata rata pengidap TBC kehilangan waktu produktifnya 3 sampai 4 bulan. Karena tubuhnya akan terasa lemas dan mudah lelah. Bahkan dalam kondisi darurat biasanya TBC akan menyebabkan tubuh menjadi lemah tak berdaya.

Dampak bagi keluarga adalah rentan tertular TBC, termasuk anak atau orang lain yang berada dalam satu rumah. Jika ada satu anggota keluarga mengidap penyakit menular TBC biasanya akan sulit untuk bergaul bahkan dengan keluarganya sendiri. Jika melihat data di NTT, pendapatan keluarga turun $20 \%$ sampai $30 \%$ ketika ada 1 anggota keluarga yang mengidap penyakit TBC. Itu dikarenakan kebanyakan yang mengidap TBC tidak dapat bekerja.

\section{Dampak penyakit menular PMS (Penyakit Menular Seks)}

Seperti yang sudah dijelaskan diatas, Penyakit Seks Menular ini sangat berbahaya dan berdampak buruk bagi orang di sekitar penderitanya. Penyebab PMS sendiri adalah bisa dari hubungan seks tidak sehat, bergonta ganti pasangan dan penyakit ini bisa meular dari ibu ke anak melalui ASI.

Jika kita melihat dampak yang ditimbulkan biasanya sedikit menakutkan karena, penyakit seks ini bermacam - macam mulai dari sipilis, HIV/AIDS dan lain sebagainya. Kondisi fisik pengidap penyakit menular seks ini biasanya lemah dan sulit melakukan aktifitas seperti biasanya. Jika seseorang didalam rumah mengidap penyakit ini, alangkah baiknya anggota keluarga yang lain memberikan perhatian yang khusus seperti pemberian alat sehari hari tersendiri (alat makan, alat mandi, dll) dan pisahkan dari anggota keluarga yang lain.

Tapi disisi psikologi, jangan sampai menjauhi penderitanya tetap berikan perhatian seperti sering komunikasi bersama keluarga dan diajak bercanda. Berikan semangat kepada penderita supaya tetap memiliki optimisme. Ada satu hal yang diperaya mampu mengobati segala penyakit yaitu sugesti. Sugesti yang berasal dari dalam akan mampu membuat tubuh bekerja optimal dalam melawan penyakit bahkan penyakit ganas 
sekalipun. Kebalikannya jika orang pesimis dan tak memiliki kekuatan pikiran untuk sembuh, bisa saja penyakit ringan sekalipun akan sulit disembuhkan.

\subsubsection{Penyakit Menular (COVID-19)}

Saat ini, kita dikejutkan dengan kemunculan virus jenis baru yang belum pernah diidentifikasi sebelumnya pada manusia yaitu Coronavirus Disease (COVID-19).

Penyakit ini pertama kali diidentifikasi pada Desember, 2019 di Wuhan, ibu kota provinsi Hubei China, dan sejak saat itu menyebar secara global, mengakibatkan pandemi yang berkelanjutan. Pada 4 Mei 2020, lebih dari 3,56 juta kasus telah dilaporkan di 187 negara dan wilayah, yang melibatkan lebih dari 251.000 kematian. Lebih dari 1,6juta orang telah pulih. Virus ini dianggap alami dan berasal dari hewan, melalui infeksi spillover. Asal sebenarnyatidak diketahui, tetapi kasus infeksi pertama yang diketahui terjadi di Cina. Pada Desember 2019, penyebaran infeksi hampir seluruhnya didorong oleh penularan dari manusia ke manusia. Sebuah studi terhadap 41 kasus pertama COVID-19 terkonfirmasi, yang diterbitkan pada Januari 2020 di TreLace mengungkapkan tanggal paling awal timbulnya gejala sebagai $1 \quad$ Desember 2019. Publikasi resmi dari WHO melaporkan timbulnya gejala paling awal sebagai 8 Desember 2018. Penularan dari manusia ke manusia dikonfirmasi oleh WHO dan otoritas Cina pada 20 Januari.

\subsubsection{Pengertian COVID-19}

Coronavirus Disease (COVID-19) adalah virus jenis baru yang belum pernah diidentifikasi sebelumnya pada manusia. Penyakit Coronavirus 2019 (COVID-19) adalah penyakit menular yang disebabkan oleh sindrom pernapasan akut coronavirus 2 (SARS- CoV-2). Coronavirus atau virus corona merupakan keluarga besar virus yang menyebabkan infeksi saluran pernapasan atas ringan hingga sedang, seperti penyakit flu. Banyak orang terinfeksi virus ini, setidaknya satu kali dalam hidupnya.

Namun, beberapa jenis virus corona juga bisa menimbulkan penyakit yang lebih serius, 
seperti:

- Middle East Respiratory Syndrome(MERS-CoV).

- Severe Acute Respiratory Syndrome(SARS-CoV).

- Pneumonia.

SARS yang muncul pada November 2002 di Tiongkok, menyebar ke beberapa negara lain. Mulai dari Hongkong, Vietnam, Singapura, Indonesia, Malaysia, Inggris, Italia, Swedia, Swiss, Rusia, hingga Amerika Serikat. Epidemi SARS yang berakhir hingga pertengahan 2003 itu menjangkiti 8.098 orang di berbagai negara. Setidaknya 774 orang mesti kehilangan nyawa akibat penyakit infeksi saluran pernapasan berat tersebut.

Sampai saat ini terdapat tujuh coronavirus (HCoVs) yang telah diidentifikasi, yaitu:

- HCoV-229E.

- $\mathrm{HCOV}-\mathrm{OC} 43$.

- HCoV-NL63.

- HCoV-HKU1.

- SARS-COV (yang menyebabkan sindrom pernapasan akut).

- $\quad$ MERS-COV (sindrom pernapasan Timur Tengah).

- COVID-19 atau dikenal juga dengan Novel Coronavirus (menyebabkan wabah pneumonia di kota Wuhan, Tiongkok pada Desember 2019, dan menyebar ke negara lainnya mulai Januari 2020. Indonesia sendiri mengumumkan adanya kasus covid 19 dari Maret 2020.

\subsubsection{Faktor Risiko Infeksi Coronavirus}

Siapa pun dapat terinfeksi virus corona. Akan tetapi, bayi dan anak kecil, serta orang dengan kekebalan tubuh yang lemah lebih rentan terhadap serangan virus ini. Selain itu, kondisi musim juga mungkin berpengaruh. Contohnya, di Amerika Serikat, infeksi virus corona lebih umum terjadi pada musim gugur dan musim dingin.

Di samping itu, seseorang yang tinggal atau berkunjung ke daerah atau negara yang 
rawan virus corona, juga berisiko terserang penyakit ini. Misalnya, berkunjung ke Tiongkok, khususnya kota Wuhan, yang pernah menjadi wabah COVID-19 yang bermulai pada Desember 2019.

\subsubsection{Tanda Dan Gejala}

\begin{tabular}{|c|c|}
\hline \multicolumn{2}{|c|}{ Gejala COVID-19 } \\
\hline Gejala & Jarak \\
\hline Demam & $83-99 \%$ \\
\hline Batuk & $59-82 \%$ \\
\hline Kehilangan selera makan & $40-84 \%$ \\
\hline Kelelahan & $44-70 \%$ \\
\hline Sesak napas & $31-40 \%$ \\
\hline Batuk berdahak & $28-33 \%$ \\
\hline Nyeri dan nyeri otot & $11-35 \%$ \\
\hline
\end{tabular}

Demam adalah gejala yang paling umum, meskipun beberapa orang yang lebih tua dan mereka yang memiliki masalah kesehatan lainnya mengalami demam di kemudian hari. Dalam satu penelitian, $44 \%$ orang mengalami demam ketika mereka datang ke rumah sakit, sementara $89 \%$ mengalami demam di beberapa titik selama dirawat di rumah sakit.

Gejala umum lainnya termasuk batuk, kehilangan nafsu makan, kelelahan, sesak napas, produksi dahak, dan nyeri otot dan sendi. Gejala seperti mual, muntah, dan diare telah diamati dalam berbagai persentase. Gejala yang kurang umum termasuk bersin, pilek, atau sakit tenggorokan.

Beberapa kasus di China awalnya hanya disertai sesak dada dan jantung berdebar.

Penurunan indra penciuman atau gangguan dalam rasa dapat terjadi. Kehilangan bau 
adalah gejala yang muncul pada 30\% kasus yang dikonfirmasi di Korea Selatan.

Seperti yang umum dengan infeksi, ada penundaan antara saat seseorang pertama kali terinfeksi dan saat ia mengalami gejala. Ini disebut masa inkubasi . Masa inkubasi untuk COVID-19 biasanya lima sampai enam hari tetapi dapat berkisar dari dua hingga 14 hari, meskipun 97,5\% orang yang mengalami gejala akan melakukannya dalam 11,5 hari infeksi.

Sebagian kecil kasus tidak mengembangkan gejala yang terlihat pada titik waktu tertentu. Pembawatanpagejalainicenderung tidak diuji, dan perannyadalam transmisi belum sepenuhnya diketahui. Namun, bukti awal menunjukkan bahwa mereka dapat berkontribusi pada penyebaran penyakit. Pada Maret 2020, Pusat Pengendalian dan Pencegahan Penyakit Korea (KCDC) melaporkan bahwa 20\% dari kasus yang dikonfirmasi tetap tanpa gejala selama tinggal di rumah sakit.

\subsubsection{Penularan}

COVID-19 adalah penyakit baru, dan cara penyebarannya di antara orang-orang sedang diselidiki, termasuk: peran utama tetesan kecil, sejauh mana dan bagaimana ia dapat ditularkan melalui udara, dan berapa lama tetesan yang dikeluarkan tetap menular pada permukaan. Penyakit ini menyebar selama kontak dekat, seringkali oleh tetesan kecil yang dihasilkan selama batuk, bersin, atau berbicara. Selama kontak dekat, (1 hingga 2 meter, 3 hingga 6 kaki), orang tertular penyakit ini setelah menghirup tetesan yang terkontaminasi yang dihembuskan oleh orang yang terinfeksi. Namun, tetesannyarelatif berat dan biasanyajatuh ke tanah atau permukaan, dan tidak menular pada jarak yang jauh. Setelah tetesan jatuh ke lantai atau permukaan, mereka masih dapat menginfeksi orang lain, jika mereka menyentuh permukaan yang terkontaminasi dan kemudian mata, hidung atau mulut mereka dengan tangan yang tidak dicuci. Pada permukaan, jumlah virus aktif berkurang dari waktu ke waktu hingga tidak lagi menyebabkan infeksi. Namun, secara eksperimental, virus dapat bertahan di berbagai permukaan selama beberapa waktu, (misalnya tembaga atau kardus selama beberapa jam, dan plastik atau baja selama beberapa hari). Permukaan mudah didekontaminasi 
dengan desinfektan rumah tangga yang membunuh virus di luar tubuh manusia atau di tangan. Desinfektan atau pemutih bukanlah pengobatan untuk COVID-19, dan menyebabkan masalah kesehatan jika tidak digunakan dengan benar, seperti di dalam tubuh manusia.

Dahak dan air liur membawa sejumlah besar virus. Beberapa prosedur medis dapat menyebabkan virus ditransmisikan lebih mudah dari biasanya untuk tetesan kecil seperti itu, yang dikenal sebagai transmisi udara.

Virus ini paling menular selama tiga hari pertama setelah timbulnya gejala, meskipun penyebaran diketahui terjadi hingga dua hari sebelum gejalamuncul (penularan secara asimptomatik) dan pada tahap selanjutnya dari penyakit. Beberapa orang telah terinfeksi dan pulih tanpa menunjukkan gejala, tetapi ketidakpastian tetap dalam hal penularan asimptomatik.

Meskipun COVID-19 bukan infeksi menular seksual, dicium, hubungan intim, dan rute oral feses diduga menularkanvirus

Awalnya, virus corona jenis COVID-19 diduga bersumber dari hewan. Virus corona COVID-19 merupakan virus yang beredar pada beberapa hewan, termasuk unta, kucing, dan kelelawar. Sebenarnya virus ini jarang sekali berevolusi dan menginfeksi manusia dan menyebar ke individu lainnya. Namun, kasus di Tiongkok kini menjadi bukti nyata kalau virus ini bisa menyebar dari hewan ke manusia. Bahkan, kini penularannya bisa dari manusia ke manusia.

\subsubsection{Diagnosa}

WHOtelahmenerbitkan beberapaprotokol pengujianuntukpenyakitini. Metode pengujian standar adalah reaksi berantai reverse transcription polymerase chain (rRT- PCR). Tes ini biasanya dilakukan pada sampel pernapasan yang diperoleh dari swab 
nasofaring ; Namun, sampel usap hidung atau dahak juga dapat digunakan. Hasil umumnya tersedia dalam beberapa jam hingga dua hari. Tes darah dapat digunakan, tetapi ini membutuhkan dua sampel darah yang diambil terpisah dua minggu, dan hasilnya memiliki sedikit nilai langsung. Ilmuwan Cina mampu mengisolasi strain virus corona dan menerbitkan urutan genetik sehingga laboratorium di seluruh dunia dapat secara independen mengembangkan tes reaksi rantai polimerase (PCR) untuk mendeteksi infeksi oleh virus. Pada 4 April 2020 , tes antibodi (yang dapat mendeteksi infeksi aktif dan apakah seseorang telah terinfeksi di masa lalu) sedang dalam pengembangan, tetapi belum banyak digunakan. Pengalaman China dalam pengujian telah menunjukkan keakuratannya hanya 60 hingga 70\%. FDA di Amerika Serikat menyetujui tes titik perawatan pertama pada 21 Maret 2020 untuk digunakan pada akhir bulan itu.

Pedoman diagnostik yang dikeluarkan oleh Rumah Sakit Zhongnan dari Universitas Wuhan menyarankan metode untuk mendeteksi infeksi berdasarkan fitur klinis dan risiko epidemiologis. Ini melibatkan mengidentifikasi orang-orang yang memiliki setidaknya dua dari gejala berikut selain riwayat perjalanan ke Wuhan atau kontak dengan orang yang terinfeksi lainnya: demam, gambaran pencitraan pneumonia, jumlah sel darah putih normal atau berkurang, atau berkurangnya jumlah limfosit.

Sebuah penelitian meminta pasien COVID-19 yang dirawat di rumah sakit untuk batuk ke dalam wadah steril, sehingga menghasilkan sampel air liur, dan mendeteksi virus pada sebelas dari dua belas pasien yang menggunakan RT-PCR. Teknik ini memiliki potensi lebih cepat daripada swab dan melibatkan risiko yang lebih kecil bagi petugas kesehatan (pengumpulan di rumah atau di dalam mobil).

Seiring dengan pengujian laboratorium, CT scan dada mungkin membantu untuk mendiagnosis COVID-19 pada individu dengan kecurigaan klinis yang tinggi terhadap infeksi tetapi tidak direkomendasikan untuk skrining rutin. Kekeruhan tanah-kaca multilobar bilateral dengan distribusi perifer, asimetris, dan posterior sering terjadi pada infeksi awal. Dominasi subpleural, paving gila (penebalan septum lobular dengan pengisian alveolar variabel), dan konsolidasi dapat muncul saat penyakit berkembang. 
Pada akhir 2019, WHO menetapkan kode penyakit ICD-10 darurat U07.1 untuk kematian akibat infeksi SARS-CoV-2 yang dikonfirmasi laboratorium dan U07.2 untuk kematian akibat COVID yang didiagnosis secara klinis atau epidemiologis-19 tanpa SARS-CoV-yang dikonfirmasi laboratorium. 2 infeksi.

\subsubsection{Komplikasi}

Pada beberapa orang, penyakit ini dapat berkembang menjadi pneumonia, kegagalan multiorgan, dan kematian. Manifestasi neurologis termasuk kejang, stroke, ensefalitis , dan sindrom Guillain-Barré. Komplikasi yang berhubungan dengan kardiovaskular mungkin termasuk gagal jantung, aktivitas listrik yang tidak teratur, pembekuan darah, dan peradangan jantung. [58]

Pada beberapa orang, COVID-19 dapat mempengaruhi paru-paru yang menyebabkan pneumonia . Pada mereka yang paling parah terkena dampaknya, COVID-19 dapat dengan cepat berkembang menjadi sindrom gangguan pernapasan akut (ARDS) yang menyebabkan kegagalan pernapasan, syok septik, atau kegagalan multi-organ.

Komplikasi yang terkait dengan COVID-19 termasuk sepsis, pembekuan abnormal, dan kerusakan pada jantung, ginjal, dan hati. Abnormalitas pembekuan, khususnya peningkatan waktu protrombin, telah dijelaskan pada $6 \%$ dari mereka yang dirawat di rumah sakit dengan COVID-19, sementara fungsi ginjal abnormal terlihat pada 4\% dari kelompok ini. Sekitar 20-30\% orang yang hadir dengan COVID-19 menunjukkan peningkatan enzim hati ( transaminase ). Cedera hati seperti yang ditunjukkan oleh penanda darah kerusakan hati sering terlihat pada kasus yang parah.

\subsubsection{Perawatan}

Orang-orang dirawat dengan perawatan suportif, yang mungkin termasuk terapi cairan, dukungan oksigen, dan mendukung organ vital lainnya yang terkena dampak. 
CDC merekomendasikan agar mereka yang curiga membawa virus memakai masker wajah sederhana. Oksigenasi membran ekstrakorporeal (ECMO) telah digunakan untuk mengatasi masalah kegagalan pernapasan, tetapi manfaatnya masih dalam pertimbangan. Kebersihan pribadi dan gaya hidup serta diet yang sehat telah direkomendasikan untuk meningkatkan kekebalan tubuh. Perawatan suportif mungkin bermanfaat bagi mereka yang memiliki gejala ringan pada tahap awal infeksi.

WHO, Komisi Kesehatan Nasional China, dan Institut Kesehatan Nasional Amerika Serikat telah menerbitkan rekomendasi untuk merawat orang-orang yang dirawat di rumah sakit dengan COVID19. Intensivists dan pulmonologist di AS telah menyusun rekomendasi perawatan dari berbagai lembaga menjadi sumber daya gratis, IBCC.

\subsubsection{Pemberian Obat-Obatan}

Tak ada perawatan khusus untuk mengatasi infeksi virus corona. Umumnya pengidap akan pulih dengan sendirinya. Namun, ada beberapa upaya yang bisa dilakukan untuk meredakan gejala infeksi virus corona. Contohnya:

- Minum obat yang dijual bebas untuk mengurangi rasa sakit, demam, dan batuk. Namun, jangan berikan aspirin pada anak-anak. Selain itu, jangan berikan obat batuk pada anak di bawah empat tahun.

- Gunakan pelembap ruangan atau mandi air panas untuk membantu meredakan sakit tenggorokan danbatuk.

- Perbanyak istirahat.

- Perbanyak asupan cairan tubuh.

- Jika merasa khawatir dengan gejala yang dialami, segeralah hubungi penyedia layanan kesehatan terdekat.

Khusus untuk virus corona yang menyebabkan penyakit serius, seperti SARS, MERS, atau infeksi COVID-19, penanganannya akan disesuaikan dengan penyakit yang diidap dan kondisi pasien. 
Bila pasien mengidap infeksi novel coronavirus, dokter akan merujuk ke RS Rujukan yang telah ditunjuk oleh Dinkes (Dinas Kesehatan) setempat. Bila tidak bisa dirujuk karena beberapa alasan, dokter akan melakukan:

- Isolasi

- Serial foto toraks sesuai indikasi.

- Terapi simptomatik.

- Terapi cairan.

- Ventilator mekanik (bila gagalnapas)

- Bila ada disertai infeksi bakteri, dapat diberikan antibiotik.

Per Organisasi Kesehatan Dunia, per April 2020, tidak ada pengobatan khusus untuk COVID19. Pada tanggal 1 Mei 2020, Amerika Serikat memberikan Otorisasi Penggunaan Darurat (bukan persetujuan penuh) untuk remdesivir pada orang yang dirawat di rumah sakit dengan COVID-19 yang parah setelah sebuah penelitian menyarankan itu mengurangi durasi pemulihan. peneliti terus bekerja pada perawatan yang lebih efektif dan banyak kandidat vaksin sedang dalam tahap pengembangan atau pengujian.

Untuk gejala, beberapa profesional medis merekomendasikan parasetamol (acetaminophen) dibandingkan ibuprofen untuk penggunaan lini pertama. WHO dan NIH tidak menentang penggunaan obat antiinflamasi non-steroid (NSAID) seperti ibuprofen untuk gejala, dan FDA mengatakan saat ini tidak ada bukti bahwa NSAID memperburuk gejala COVID 19.

Sementara kekhawatiran teoritis telah diajukan tentang penghambat ACE dan penghambat reseptor angiotensin, pada 19 Maret 2020, ini tidak cukup untuk membenarkan menghentikan obat-obatan ini. Satu studi dari 22 April menemukan bahwa orang dengan COVID-19 dan hipertensi memiliki angka kematian semua penyebab yang lebihrendaketkamenggunakan obat ini.

Steroid, seperti metilprednisolon, tidak dianjurkan kecuali penyakitnya dipersulit oleh 
sindrom gangguan pernapasan akut.

Perhimpunan Imunologi dan Alergi Klinis Australasia merekomendasikan bahwa tocilizumab harus dipertimbangkan sebagai opsi perawatan tanpa label bagi mereka yang mengalami sindrom kesulitan pernapasan akut yang terkait dengan COVID-19. Ini merekomendasikan ini karena manfaatnya yang diketahui dalam badai sitokin yang disebabkan oleh pengobatan kanker tertentu , dan bahwa badai sitokin mungkin merupakan kontributor signifikan terhadap kematian pada COVID-19 yang parah.

Pengobatan untuk mencegah pembekuan darah telah disarankan untuk pengobatan, dan terapi antikoagulan dengan heparin dengan berat molekul rendah tampaknya terkait dengan hasil yang lebih baik pada COVID parah-19 yang menunjukkan tanda-tanda koagulopati (peningkatan Ddimer).

\subsubsection{Pencegahan}

Langkah-langkah pencegahan untuk mengurangi kemungkinan infeksi termasuk tinggal di rumah, menghindari tempat-tempat ramai, menjaga jarak dari orang lain, sering mencuci tangan dengan sabun dan air dan setidaknya selama 20 detik, mempraktikkan kebersihan pernapasan yang baik, dan menghindari menyentuh mata, hidung, atau mulut dengan tangan yang tidak dicuci. CDC merekomendasikan untuk menutup mulut dan hidung dengan tisu saat batuk atau bersin dan merekomendasikan penggunaan bagian dalam siku jika tidak ada jaringan yang tersedia. Kebersihan tangan yang tepat setelah batuk atau bersin dianjurkan. CDC telah merekomendasikan penggunaan penutup wajah kain dalam pengaturan publik di mana langkahlangkah sosialjarakjauh sulit dipertahankan, sebagian untuk membatasi penularan oleh individu tanpa gejala. Pedoman National Institutes of Health AS tidak merekomendasikan obat apa pun untuk pencegahan COVID-19, sebelum atau setelah terpapar virus SARS-CoV-2, di luar pengaturan uji klinis.

Strategi menjauhkan sosial bertujuan untuk mengurangi kontak orang yang terinfeksi 
dengan kelompok besar dengan menutup sekolah dan tempat kerja, membatasi perjalanan, dan membatalkan pertemuan publik besar. Pedoman jarak jauh juga mencakup bahwa orang harus terpisah setidaknya 1,8 meter. Tidak ada obat yang diketahui efektif mencegah COVID-19. Setelah pelaksanaan perintah sosial untuk menjaga jarak dan tinggal di rumah, banyak daerah telah mampu mempertahankan tingkat penularan yang efektif (" Rt ") kurang dari satu, yang berarti penyakit ini dalam remisi di daerah-daerah tersebut. Dalam model yang sederhana kebutuhan rata-rata dari waktu ke waktu dijaga pada atau di bawah nol untuk menghindari pertumbuhan eksponensial.

Sebagai vaksin yang diperkirakan paling lambat hingga 2021,bagian kunci dari pengelolaan COVID-19 sedang mencoba untuk mengurangi dan menunda puncak epidemi, yang dikenal sebagai "perataan kurva ". Hal ini dilakukan dengan memperlambat laju infeksi untuk mengurangi risiko kewalahan layanan kesehatan, memungkinkan penanganan kasus yang lebih baik, dan menunda kasus tambahan hingga tersedia pengobatan atau vaksin yang efektif.

Menurut WHO, penggunaan masker direkomendasikan hanya jika seseorang batuk atau bersin atau ketika seseorang merawat seseorang dengan dugaan infeksi. Untuk masker wajah Pusat Pencegahan dan Pengendalian Penyakit Eropa (ECDC) "... dapat dipertimbangkan terutama ketika mengunjungi ruang tertutup yang sibuk _ ... "tapi" ... hanya sebagai langkah pelengkap ... " Beberapa negara telah merekomendasikan bahwa orang sehat mengenakan masker wajah atau kain penutup wajah (seperti syal atau bandana) setidaknya dalam pengaturan publik tertentu, termasuk Cina, Hong Kong, Spanyol, Italia (wilayah Lombardy), Rusia, dan Amerika Serikat. Mereka yang didiagnosis dengan COVID-19 atau yang percaya bahwa mereka mungkin terinfeksi disarankan oleh CDC untuk tinggal di rumah kecuali untuk mendapatkan perawatan medis, hubungi sebelum mengunjungi penyedia layanan kesehatan, mengenakan masker sebelum memasuki kantor penyedia layanan kesehatan dan ketika di ruangan mana pun atau kendaraan dengan orang lain, tutupi batuk dan bersin dengan tisu, cuci tangan dengan sabun dan air secara teratur dan hindari berbagi barang-barang rumah tangga pribadi. CDC juga merekomendasikan agar orang sering mencuci tangan dengan sabun dan air 
setidaknya selama20 detik, terutama setelah pergi ke toilet atau ketika tangan terlihat kotor, sebelum makan dan setelah meniup hidung, batuk, atau bersin. Lebih lanjut merekomendasikan menggunakan sanitiser tangan berbasis alkohol dengan setidaknya $60 \%$ alkohol, tetapi hanya ketika sabun dan air tidak tersedia.

Untuk daerah di mana sanitiser tangan komersial tidak tersedia, WHO menyediakan dua formulasi untuk produksi lokal. Dalam formulasi ini, aktivitas antimikroba muncul dari etanol atau isopropanol . Hidrogen peroksida digunakan untuk membantu menghilangkan spora bakteri dalam alkohol; itu "bukan zat aktif untuk antisepsis tangan". Gliserol ditambahkan sebagai humektan.

\section{BAB III}

\section{Penutup}




\subsection{Kesimpulan}

Berdasarkan beberapa uraian di atas dapat di simpulkan bahwa penyakit menular menjadi salah satu penyebab utama kematian di dunia. Kondisi ini semakin buruk dengan kondisi lingkungan yang tidak sehat menyebabkan beberapa penyakit infeksi akut yang berbahaya menyerang manusia seperti penyakit yang bersumber pada binatang. Penyakit ini dapat berpindah dari satu orang ke orang lain, penularannya tersebut bisa terjadi secara langsung atau tidak langsung dan juga bisa menular melalui perantara atau penghubung. Penyakit menular biasanya ditandai dengan adanya penyebab penyakit yang hidup dan bisa berpindah menyerang inang (penderita).penyakit menular disebabkan oleh agen biologi seperti halnya virus, bakteria, atau parasit dan bukan disebabkan oleh faktor fisik seperti luka bakar atau zat kimia (keracunan).

Saat ini, terdapat kemunculan virus jenis baru yang belum pernah diidentifikasi sebelumnya pada manusia yaitu Coronavirus Disease (COVID-19). Penyakit ini pertama kali diidentifikasi pada Desember, 2019 di Wuhan, ibu kota provinsi Hubei China, dan sejak saat itu menyebar secara global, mengakibatkan pandemi yang berkelanjutan yang memakan banyak korban.Virus ini dianggap alami dan berasal dari hewan.

\subsection{Saran}

Penyakit menular merupakan penyakit yang harus diwaspadai. Pasalnya, beberapa dari penyakit menular dapat ditularkan melalui udara, dan pada umumnya, penyakit menular dapat menyebabkan kematian. Oleh karena itu, kita harus menjaga kesehatan tubuh dengan mengonsumsi vitamin $\mathrm{C}$ guna membangun daya tahan tubuh, menjaga kebersihan diri dan linkungan, memakan makanan yang sehat dan bergzi, dan olahraga yang teratur. 


\section{Daftar Pustaka}

Coronavirus, https://www.halodoc.com/kesehatan/coronavirus Hepatitis,

https://www.alodokter.com/hepatitis

Penyakit Menular : Macam Jenis, Penyebab, Dampak Akibat, dan Contoh, jagad.id/penyakit-menular/

Penyakit Virus Corona 2019,

https://translate.googleusercontent.com/translate_c?client=srp\&depth+1

$\& h l+i d \& n v=1 \&$ rurl=translate.google.com \&sl=en \&sp=nmt4\&tl=id\&u=https://

en.m.wikipedia.org/wiki/Coronavirus_disease_2019\&usg=ALkjrhjQuvcZ3d bZhRwbBxKOGTf-rM24A

Rotavirus, https://www.alodokter.com/rotavirus 